\title{
Influence of Nano-silica and Crack Width on Corrosion Parameters of Pre-cracked Reinforced Concrete Beams
}

\author{
Naser Nosratzehi ${ }^{1}$, Mahmoud Miri ${ }^{1 *}$ \\ ${ }^{1}$ Department of Civil Engineering, University of Sistan and Baluchestan, P.O. Box 9816745563-161, Zahedan, Iran \\ * Corresponding author, e-mail: mmiri@eng.usb.ac.ir
}

Received: 20 May 2020, Accepted: 19 January 2021, Published online: 05 February 2021

\begin{abstract}
This paper presents an experimental study on the durability of both sound and cracked reinforced concrete (RC) beam specimens. Using nano-silica (NS) can improve the durability properties of reinforced concrete. So, RC beams with three nano-silica percentages of $0 \%, 1.5 \%$, and $3 \%$ were prepared. In addition, to consider the effect of cracking on corrosion, crack widths between $0.1 \mathrm{~mm}$ and $0.5 \mathrm{~mm}$, and cover depths of $30 \mathrm{~mm}$ and $45 \mathrm{~mm}$ were considered. All beam specimens were subjected to $5 \% \mathrm{NaCl}$ solution and monitored weekly for half-cell potentials (HCP). The presented results include the HCP evaluation and diffusion factor values in sound and cracked concrete beams exposed to chloride attack. The experimental results indicated that the chloride diffusion coefficient increases with extending crack width. Nano-silica improved the permeability characteristics of concrete, HCP and also diffusion factor values. Regressive models of the chloride diffusion factor and HCP values were proposed for influencing parameters, i.e., nano-silica and crack width with two different cover depths.
\end{abstract}

Keywords

corrosion, nano-silica, half-cell potential, diffusion coefficient, cracked concrete, cover depth

\section{Introduction}

Durability of reinforced concrete structures is a major problem all around the world [1]. Deterioration of reinforced concrete structures at the early stages is a sign of serious problems with durability. Therefore, it is beneficial to understand the factors affecting concrete durability to propose solutions [2]. The main cause of corrosion in reinforced concrete is the penetration of chloride ions, and it is controlled by several factors such as the quality of concrete, cover depth, and service load cracks [3]. Consequently, when cracks appear in the concrete cover, the corrosion problem will be worse in RC structures.

Corrosion may lead to loss of the cross-section and decrease in strength of steel bars, loss of bond between the concrete and steel bar, and also volume expansion of steel which causes cracks in concrete cover [4]. In the absence of cracks, concrete is watertight, providing that it is properly placed, compacted, and cured. Cracking may occur because of creep, shrinkage, cycles of freezing and thawing, external loads, etc. [5]. Concrete becomes vulnerable to the deterioration caused by the corrosion of reinforcement as it gradually loses its water-tightness during service life. However, in most cases, the capacity of the concrete structure to carry loads is not influenced by cracks, but cracks may affect its durability adversely by providing easy access to corrosive agents, especially chloride ions [6]. So cracks increase the risk of corrosion by facilitating the local ingress of substances [7]. It is also indicated by laboratory researches that cracks may hasten the initiation of reinforced concrete corrosion [8]. Several attempts have been made to find a correlation between the cracks and the risk of corrosion. After a relatively short exposure time (less than three years), a good correlation between crack width and corrosion behavior can be observed [9]. It has been reported that wider surface cracks trigger corrosion more rapidly than smaller ones [10].

Some other researchers believe that the initiation of steel corrosion is slower when the cover depth is increased in cracked concrete [11]. Nevertheless, improving the quality of cover (by using supplementary materials or by reducing the water-to-binder ratio) can change the effect of crack width. This means that, for a constant crack width, covers with good quality can delay the initiation of 
corrosions [12]. So, a single relation can't be used to evaluate the effect of crack width on the corrosion during the early exposure periods.

Nano science and technology is a recent field in materials science and engineering. Nanoparticles are the most important products of nanotechnology [13]. In the field of concrete technology, nanoparticles are used to increase the durability and strength of concrete [14]. Among the nanoparticles, nano-silica has attracted the attention of several researchers because it has excellent pozzolanic activity in cement-based materials [15]. Some researchers have studied the effects of nano- $\mathrm{SiO}_{2}$ particles on the performance of cement-based materials such as mortar, cement paste, and concrete [16]. Nano-silica particles improve the mechanical properties and durability characteristics of cement-based materials by enhancing the density of the binding matrix and improving the interfacial transition zone (ITZ) between aggregates and the cement paste [17]. Du et al. [18] studied the durability properties of concrete containing nano-silica at small dosages of $0.3 \%$ and $0.9 \%$, respectively. The use of low dosages of nano-silica results in a combined contribution of the nanofiller effect and the pozzolanic reaction. This means that the beneficial effects of nano-silica can be obtained with lower dosages of nanoparticles [19]. If more than $5 \%$ of nano-silica replaces cement, it may have adverse effects on the durability and mechanical characteristics of concrete [16].

Various tests can be used to study the effect of nano-silica on the durability of concrete. Techniques such as linear polarization, resistivity measurement, infrared thermography, half-cell potentials (HCP), and determination of diffusion factor evaluations are used to detect corrosion and evaluate corrosive environment [20]. Among these methods, HCP as non-destructive testing (NDT) and diffusion factor method have been utilized in the current study. Half-cell potential method is used to assess the possibility of rebar corrosion, whereas it is not able to directly evaluate the corrosion rate and cracking in concrete [21]. There are several variables in reinforced concrete that must be considered in the HCP test, such as cover depth, mixing condition, and crack width. However, their effects on HCP are not quantitatively evaluated.
Although the durability of reinforced concrete is affected by a large number of factors, chloride penetration is one of the most outstanding factors causing steel corrosion [22]. Fick's second law of diffusion is the commonly used approach to predict the durability of concrete structures in chloride-induced corrosion [23].

In this paper, HCP variation and chloride content in different depths were monitored to investigate the effect of nano-silica and pre-cracks on the durability of concrete structures.

\section{Experimental program}

Experiments were designed to investigate the influence of different crack widths on corrosion propagation with varying nano-silica percentages and cover depths. For this purpose, a total number of 30 beam specimens with a size of $100 \times 100 \times 750 \mathrm{~mm}$ were cast.

\subsection{Materials}

Ordinary Portland Cement (OPC) produced according to the ASTM C150 standard [24], was used in this study. The cement had a specific surface of $2900 \mathrm{~cm}^{2} / \mathrm{g}$ and chemical specifications, as presented in Table 1. The fine aggregates consist of sand with a maximum nominal diameter of $4.75 \mathrm{~mm}$ and a fineness modulus of 3 . The specific gravity of the sand was $2.57 \mathrm{~g} / \mathrm{cm}^{3}$, and its water absorption capacity was $1.5 \%$. Moreover, the coarse aggregates with a maximum nominal diameter of $12.5 \mathrm{~mm}$ and continuous grading were used. The coarse aggregate had a specific gravity of $2.52 \mathrm{~g} / \mathrm{cm}^{3}$, water absorption capacity of $0.9 \%$, while grading of the aggregates satisfied the requirements of ASTM C33 [25]. Four steel bars with a diameter of $10 \mathrm{~mm}$ and yielding stress of $400 \mathrm{MPa}$ wer used in all samples.

Nano-silica powder was obtained from nanostructured and amorphous materials soluble in water with a concentration of 50 percent, while the average particle diameter is $25 \mathrm{~nm}$. The physical properties of nano-silica are presented in Table 2.

\subsection{Influencing parameters and mix proportions}

Three influencing parameters were considered as crack width, nano-silica percentage and cover depth. RC beams with three nano-silica percentages of $0 \%, 1.5 \%$, and $3 \%$

Table 1 Chemical composition of cement (\%)

\begin{tabular}{ccccccccccccccc}
\hline $\mathrm{C}_{2} \mathrm{~S}$ & $\mathrm{C}_{3} \mathrm{~S}$ & $\mathrm{C}_{3} \mathrm{~A}$ & $\mathrm{C}_{4} \mathrm{Af}$ & $\mathrm{Cl}$ & $\mathrm{SO}_{3}$ & $\mathrm{NaO}_{2}$ & $\mathrm{~K}_{2} \mathrm{O}$ & $\mathrm{MgO}$ & $\mathrm{Fe}_{2} \mathrm{O}_{3}$ & $\mathrm{Al}_{2} \mathrm{O}_{3}$ & $\mathrm{SiO}_{2}$ & $\mathrm{CaO}_{2}$ \\
\hline 16 & 56 & 6 & 9 & $<0.04$ & 1.4 & 0.5 & 0.6 & 3 & 5 & 5 & 21.5 & 64 \\
\hline
\end{tabular}


were prepared in samples of NS1, NS2, and NS3, respectively. Details of mix proportions are presented in Table 3.

Crack width of W1-W4 varied according to Table 4, and the cover depth of $30 \mathrm{~mm}$ and $45 \mathrm{~mm}$ were also considered for $\mathrm{C} 1$ and $\mathrm{C} 2$, respectively.

Before casting, the bars were completely cleaned using a wire brush. After 28 days of curing of concrete beams (underwater at $23 \pm 2^{\circ} \mathrm{C}$ ) and ten days of air drying, the cracks were created in the samples. The incipient cracks were produced by application of three-point machine loading with universal jack (Gotech LC7001) and measured by MATEST digital strain gauge (with an accuracy of $0.001 \mathrm{~mm}$ ), according to Fig. 1.

The W1-W4 crack widths were produced using the loading system shown in Fig. 2. Occasional unwanted cracks were sealed using a low viscosity epoxy.

\subsection{Sample monitoring}

Environmental conditions affect the penetration of chloride ions into concrete. The tidal environmental conditions are the most aggressive zone in terms of penetration of chloride ion into concrete samples [26]. Therefore, wet and dry conditions, which is a simulation of the tidal environment was considered for all samples.

All beams experienced a 7-day ponding cycle in a solution containing $5 \%$ salt and then were dried in a period of 7 days. The loading system was used to adjust the crack widths (via bolts and nuts) as required. The samples were monitored weekly for half-cell potentials for 30 weeks (see in Fig. 3).

\subsection{Half-cell potential (HCP)}

Half-cell potential technique is one of the most popular non-destructive methods to detect corrosion probability. According to ASTM C876 [21], the potential difference

\begin{tabular}{lccc}
\multicolumn{4}{c}{ Table 2 Physical properties of nano-silica } \\
\hline $\begin{array}{l}\text { Viscosity } \\
(\mathrm{mPa} . \mathrm{s})\end{array}$ & $\begin{array}{c}\text { Special weight } \\
\left(\mathrm{gr} / \mathrm{cm}^{3}\right)\end{array}$ & $\begin{array}{c}\text { Melting point } \\
\left({ }^{\circ} \mathrm{C}\right)\end{array}$ & $\mathrm{PH}$ \\
\hline$<50$ & $1.05-1.4$ & 100 & $9-11$ \\
\hline
\end{tabular}

Table 3 Details of mix proportions for RC beams $\left(\mathrm{Kg} / \mathrm{m}^{3}\right)$

\begin{tabular}{cccccc}
\hline Sand & Gravel & Cement & Water & $\begin{array}{c}\text { Superplasticizer } \\
(\%)\end{array}$ & $\begin{array}{c}\text { Nano-silica } \\
(\%)\end{array}$ \\
\hline 750 & 1050 & 400 & 180 & 1 & $0,1.5,3$ \\
\hline
\end{tabular}

Table 4 Domain of cracks width variations ( $\mathrm{mm})$

\begin{tabular}{ccccc}
\hline W0 & W1 & W2 & W3 & W4 \\
\hline 0 & $0.1-0.2$ & $0.2-0.3$ & $0.3-0.4$ & $0.4-0.5$ \\
\hline
\end{tabular}

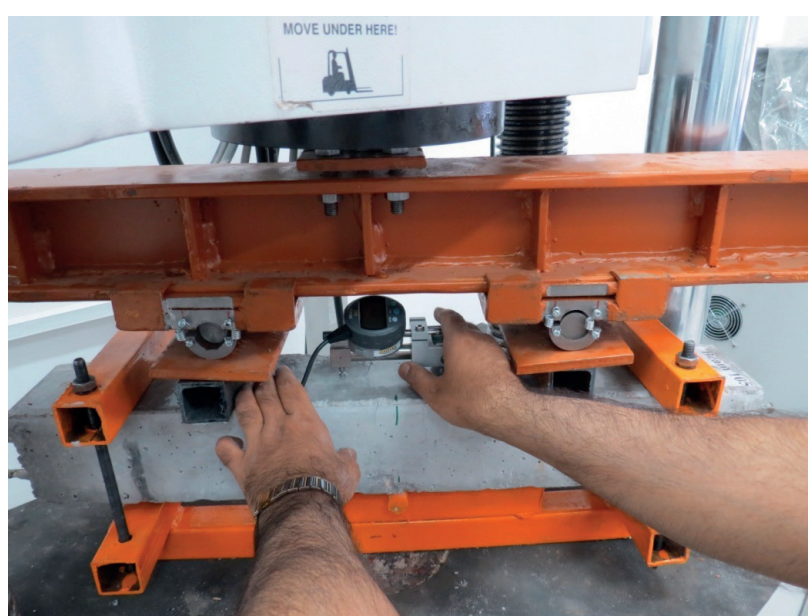

Fig. 1 Experimental set up for producing and recording incipient cracks

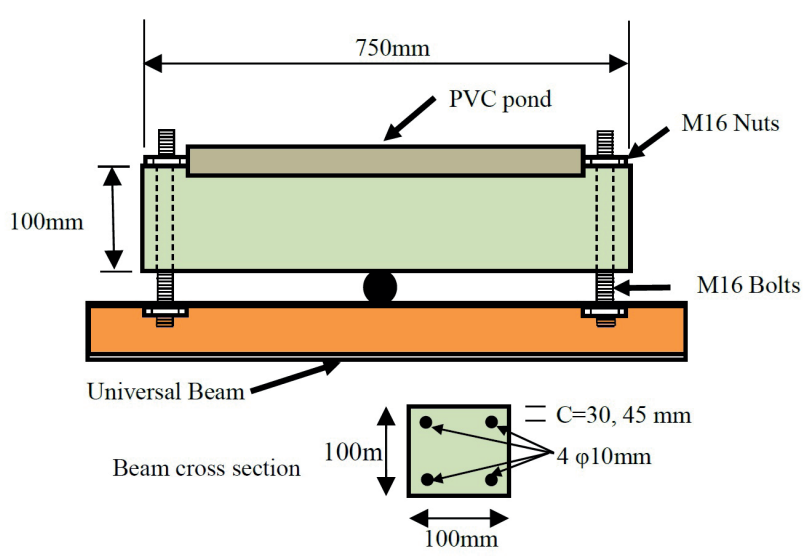

Fig. 2 Experimental beam setup

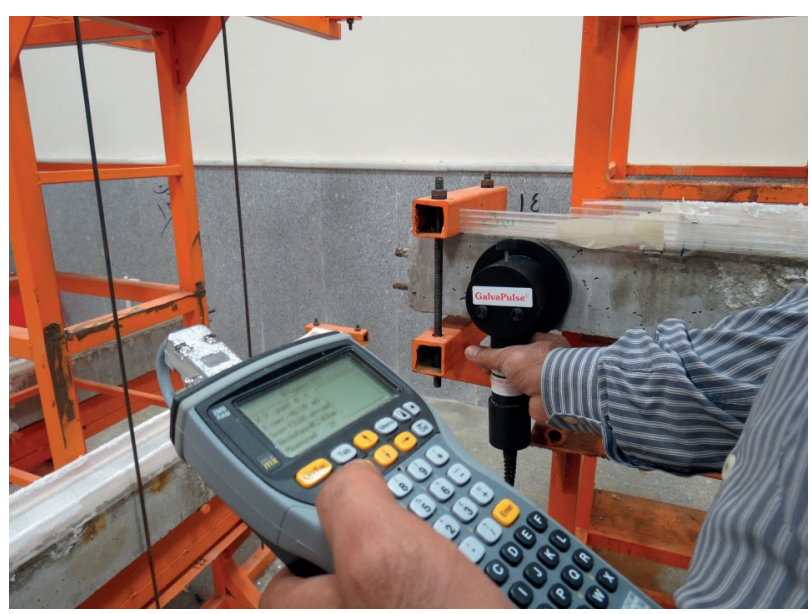

Fig. 3 Sample monitoring for half-cell potential

is measured by using a $\mathrm{Cu} / \mathrm{CuSO}_{4}$ reference electrode. If the potential difference is less than $-200 \mathrm{mV}$, the probability of corrosion is $5 \%$. However, if the potential is between $-350 \mathrm{mV}$ and $-200 \mathrm{mV}$, there is a $50 \%$ probability of corrosion in the reinforced concrete, and for values less than $-350 \mathrm{mV}$, the likelihood of corrosion is about $90 \%$ [21]. 
Measured half-cell potential difference in this study is achieved by measuring the average from the three starting, mid, and end points calculated on both sides of the beam.

\subsection{Diffusion factor}

The diffusion coefficient is a parameter that shows the resistance of concrete against the penetration of chlorides. This parameter describes the ability of concrete to resist the reaction of chlorides.

In this paper, the concentration of chloride at different concrete depths of the prepared beam samples was determined according to NT BUILD 443 [27] by powder making and titration test. The concentration of chloride was measured at nine depths of concrete samples. Then, the diffusion coefficient $\left(D_{c}\right)$ and the surface chloride $\left(C_{s}\right)$ values were obtained using the Eq. (1) [28]:

$$
C(x, t)=C_{s} \times\left(1-\operatorname{erf}\left(\frac{x}{2 \sqrt{D_{c} t}}\right)\right),
$$

where $x$ denotes the distance from the concrete surface (meter), $t$ is the exposure duration (s), $D_{c}$ is the concrete diffusion coefficient $\left(\mathrm{m}^{2} / \mathrm{s}\right) . C_{s}$ shows the weight percentage of the chloride concentration on the concrete surface, and $C(x, t)$ is the weight percentage of chloride ion at a depth of $x$ from the surface during time $t$. Moreover, erf is the error function which is expressed as follows:

$\operatorname{erf}(x)=\frac{2}{\sqrt{\pi}} \int_{0}^{x} e^{-\beta^{2}} d \beta$.

The regressive analysis of experimental data was performed by the fitting toolbox of Matlab on Eq. (1), and the values of $D_{c}$ and $C_{s}$ were obtained.

\section{Results and discussion}

\subsection{Crack effect on the values of half-cell potential}

Fig. 4 shows the results of the half-cell potential for sound and cracked reinforced concrete beams (without nanosilica). As can be seen, the measured averages of half-cell potential difference in sound concrete beams for cover depths $30 \mathrm{~mm}$ and $45 \mathrm{~mm}$ are $-323 \mathrm{mV}$ and $-243 \mathrm{mV}$, respectively. After cracking of the concrete surface in the range of $\mathrm{W} 1$, the averages HCP values reach $-400 \mathrm{mV}$ and $-325 \mathrm{mV}$ for cover depths of $30 \mathrm{~mm}$ and $45 \mathrm{~mm}$, respectively.

Cracking of concrete surface increases the permeability of the concrete and the amount of chloride ion penetration [29]. The result of this phenomenon is a half-cell potential with more negative values. As shown in Fig. 5, the $\mathrm{HCP}$ values become $29 \%$ more negative on average during the change from $\mathrm{W} 0$ to $\mathrm{W} 1$. With increasing crack width in the range of $\mathrm{W} 2$, the average $\mathrm{HCP}$ values reached $-520 \mathrm{mV}$ and $-429 \mathrm{mV}$ for cover depths of $30 \mathrm{~mm}$ and $45 \mathrm{~mm}$, respectively. According to Fig. 5, the measured difference of HCP value in the crack level of W2 relative to W0 is $68 \%$ more negative on average. Similarly, the above values for W3 and $\mathrm{W} 4$ are $78 \%$ and $79 \%$, respectively. Other studies also show that the crack width, along with various factors such as cover depth, concrete quality, and concrete resistivity are effective in corrosion rate [12].

According to ASTM C876 [21] and Fig. 4(c)-(e), the samples of W2, W3, and W4 have a $90 \%$ probability of corrosion due to the potential difference values less than $-350 \mathrm{mV}$.

Corrosion length was investigated after breaking RC beams. By increasing the width of the cracks, the corrosion length increases. The average corrosion length in samples of W1 to W4 was measured as 7, 12, 16, and 22 $\mathrm{mm}$, respectively. The negative effect of crack on the corrosion parameters was investigated by researchers [20].

\subsection{Nano-silica effect on the values of Half Cell Potential} Nano-silica is a very active artificial pozzolan in concrete technology, and its use in the manufacture of cement materials has affected their structures. In this study, nano-silica with values of $0 \%(\mathrm{NS} 0), 1.5 \%(\mathrm{NS} 1)$ and, $3 \%$ (NS2) were used as a partial replacement of cement.

In this section, half-cell potential difference changes are evaluated in beams with $45 \mathrm{~mm}$ cover depth, crack width of W1 to W4, and nano-silica percentage of NS0 to NS2. According to Fig. 6(a), the average values of halfcell potential for beams without a crack in the three mentioned categories of nano-silica are $-243 \mathrm{mV},-185 \mathrm{mV}$, and $-218 \mathrm{mV}$, respectively. The results show that by increasing the nano-silica content in NS1, HCP values become about $24 \%$ more positive, which indicates the improvement in behavior of concrete against corrosion. However, with increasing the nano-silica in NS2, the average potential difference becomes $18 \%$ more negative compared to NS1.

In Fig. 6(b)-(e), graphs of samples with cracks are provided. Average values of the potential difference for the crack of W1 in the three categories of NS0 to NS2 are $-325 \mathrm{mV},-252 \mathrm{mV}$, and $-284 \mathrm{mV}$, respectively.

As it is shown in Fig. 7, for the crack width of W1, the average value of the potential difference of NS1 is more positive than that of NS2. In the crack widths of W3 and W4, the change in average HCP values using nano-silica is slight. However, the values related to NS1 still have 


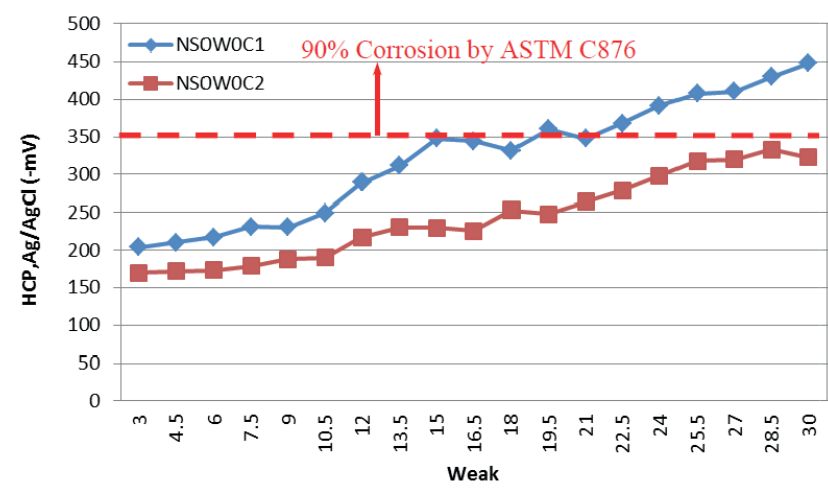

(a)

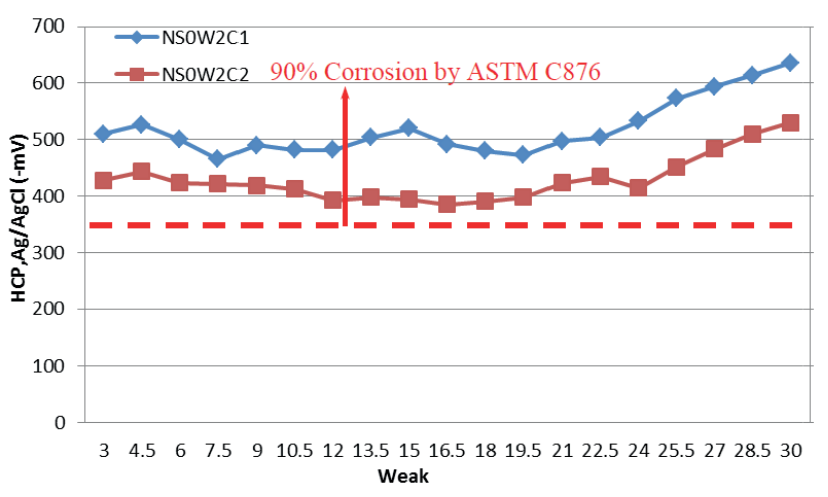

(c)

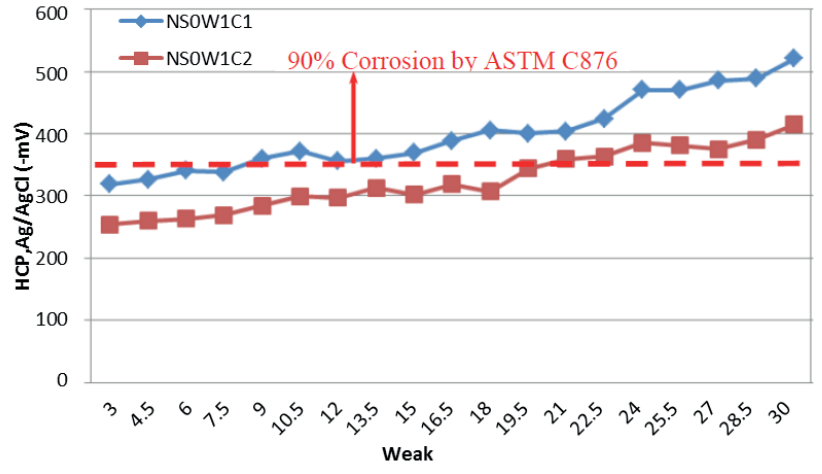

(b)

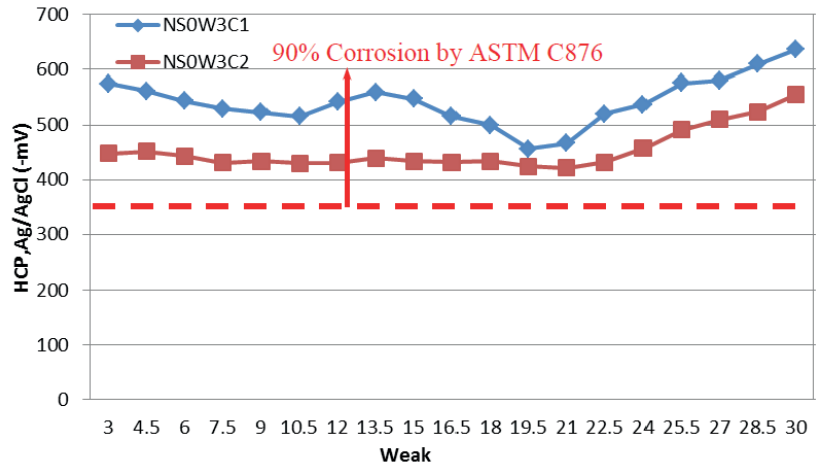

(d)

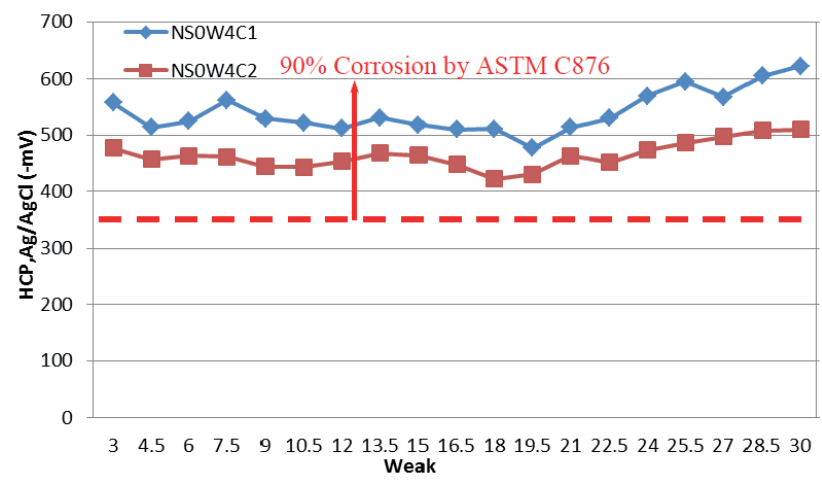

(e)

Fig. 4 Half- cell potential for sound and cracked RC beam (without nano-silica): (a) without crack, (b) crack width of $0.1 \sim 0.2 \mathrm{~mm}$, (c) crack width of $0.2 \sim 0.3 \mathrm{~mm}$, (d) crack width of $0.3 \sim 0.4 \mathrm{~mm}$, (e) crack width of $0.4 \sim 0.5 \mathrm{~mm}$. (C1 and C2 indicate the cover depth of $30 \mathrm{~mm}$ and $45 \mathrm{~mm}$, respectively)

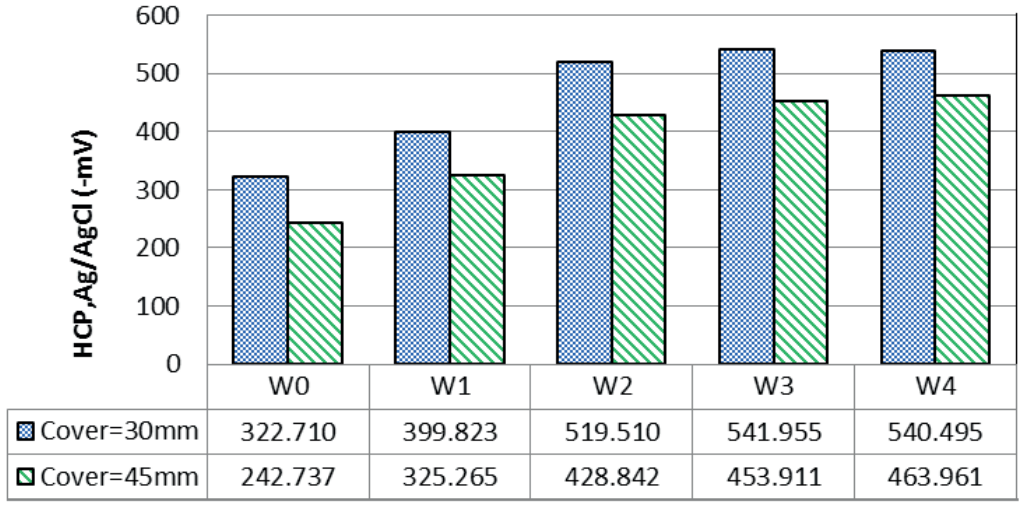

Fig. 5 Comparison of the average half-cell potential for sound and cracked RC beam (without nano-silica) 


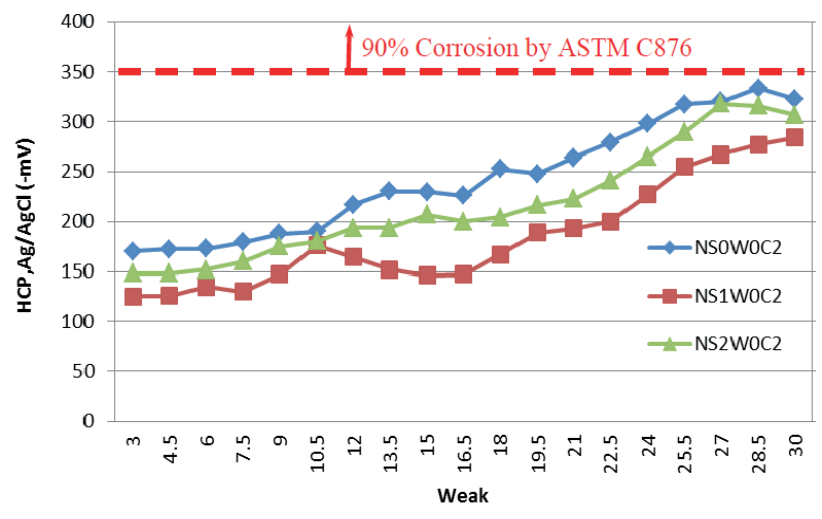

(a)

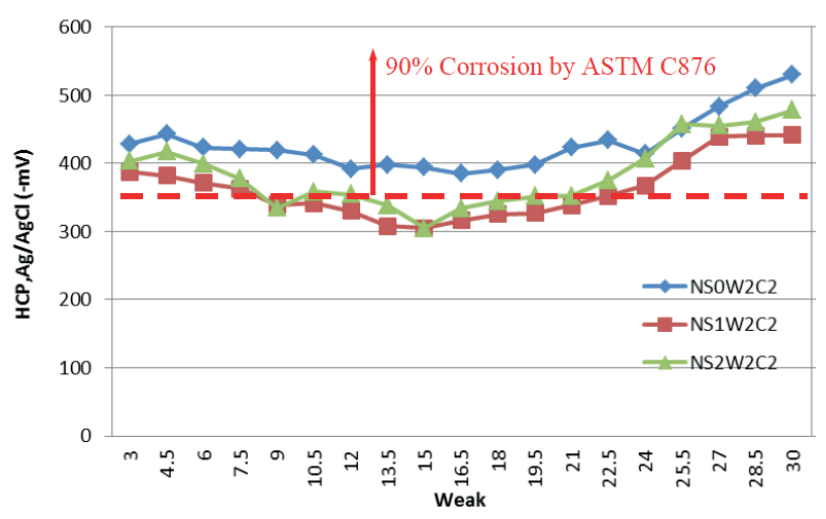

(c)

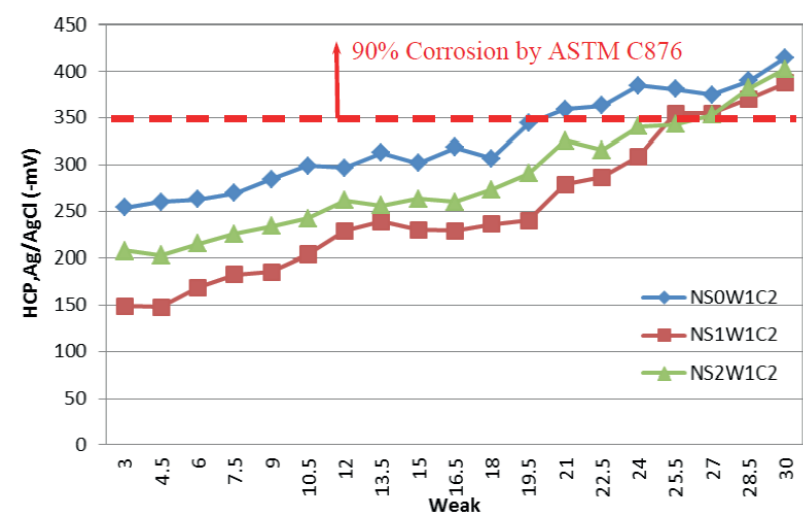

(b)

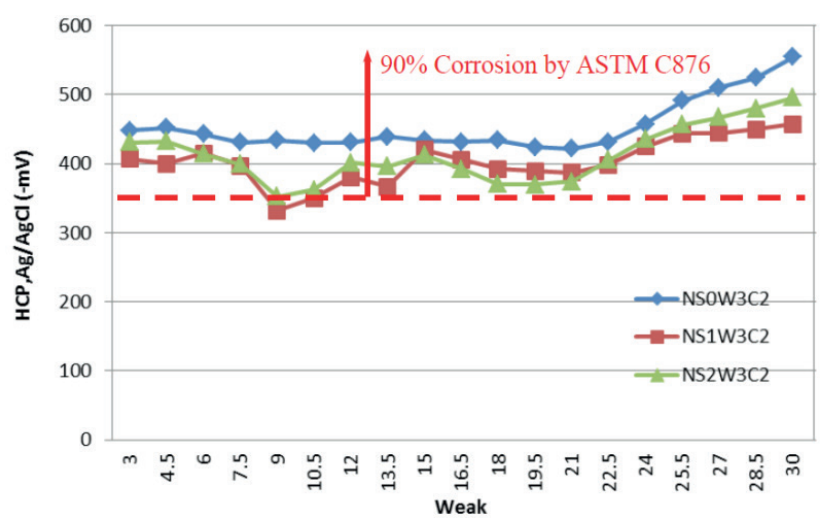

(d)

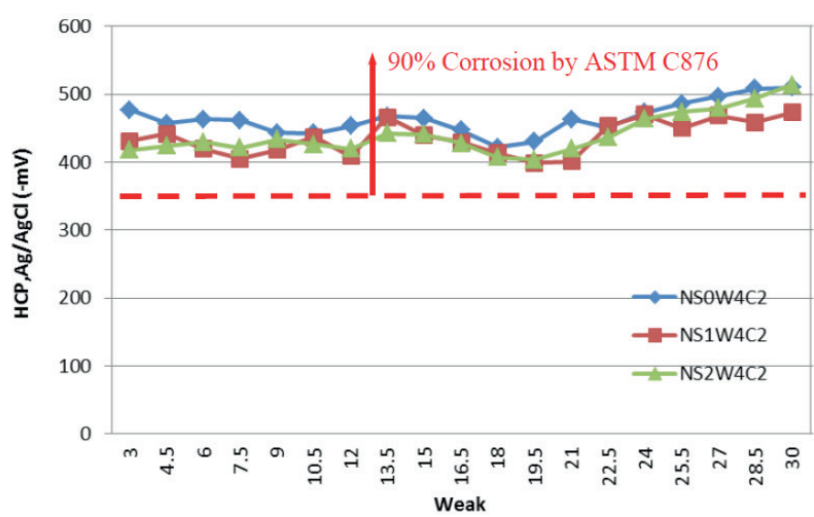

(e)

Fig. 6 Half- cell potential for RC beams containing nano-silica (with cover depths of $45 \mathrm{~mm}$ ): (a) without crack, (b) crack width of $0.1 \sim 0.2 \mathrm{~mm}$, (c) crack width of $0.2 \sim 0.3 \mathrm{~mm}$, (d) crack width of $0.3 \sim 0.4 \mathrm{~mm}$, (e) crack width of $0.4 \sim 0.5 \mathrm{~mm}$, (NS0, NS1 and NS2 indicate the nano-silica percentages of $0 \%, 1.5 \%$, and $3 \%$, respectively)

relatively more positive values. This means that nano-silica in samples of NS1 showed a more suitable behavior against corrosion. Moreover, according to ASTM C876 [21] and with regard to Fig. 6(e), the samples of W4 have $90 \%$ probability of corrosion due to potential difference values less than $-350 \mathrm{mV}$. The above results show that by increasing the crack width, the effect of nano-silica on improving the halfcell potential values decreases. However, the percentage of improvement in sound concrete containing nano-silica is more appropriate. The reason is that although nanosilica reduces the porosity of the hydrated cement by filling the voids, its effect reduces with opening cracks. Finally, in larger crack width (W4), its effect almost disappears.

\subsection{Cover depth effect on the values of half-cell potential} Cover depths used in this study are $30 \mathrm{~mm}$ (C1) and $45 \mathrm{~mm}$ (C2), whose effect will be discussed both in sound and cracked concrete beams: 


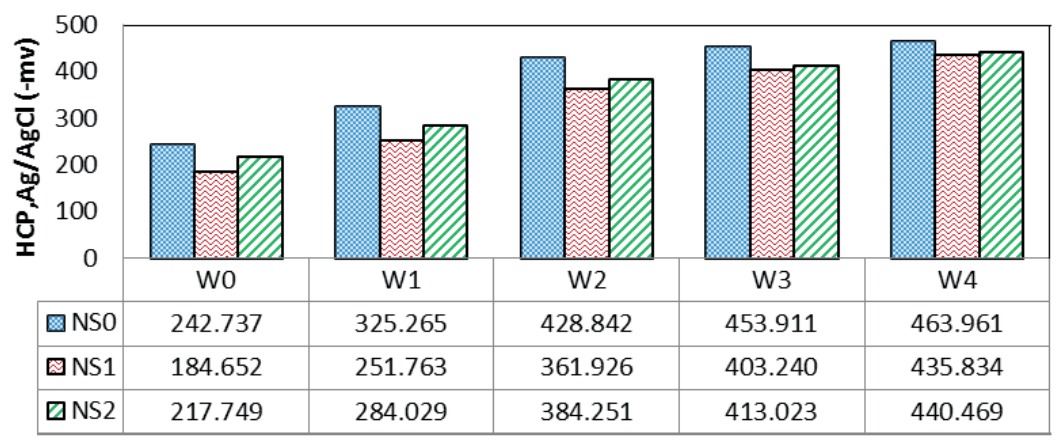

Fig. 7 Comparison between the average of half-cell potential for RC beams containing nano-silica

\subsubsection{Sound concrete beams}

In sound concrete beams, with the cover depth of $\mathrm{C} 1$ and without nano-silica (NSOW0C1), the average value of HCP is equal to $-323 \mathrm{mV}$ according to Fig. 5 . By increasing the cover depth to $\mathrm{C} 2$, the half-cell potential values show sensitivity to such a change, and the average of HCP in similar samples becomes on average $25 \%$ more positive and reaches the value of $-243 \mathrm{mV}$. In the sound concrete beam containing $1.5 \%$ of nano-silica, the average of HCP is $-232 \mathrm{mV}$ with the cover depth of $30 \mathrm{~mm}$ (NS1W0C1) and changes to $-185 \mathrm{mV}$ by increasing the cover depth to $45 \mathrm{~mm}$ in the similar sample (NS1W0C2). In specimens containing $3 \%$ of nano-silica, the value of $\mathrm{HCP}$ is $-272 \mathrm{mV}$ with the cover depth of $30 \mathrm{~mm}$ (NS2W0C1) and reaches $-218 \mathrm{mV}$ with the cover depth of $45 \mathrm{~mm}$ (NS2W0C2). This shows that the specimen with cover $\mathrm{C} 2$ performs better against corrosion than the cover $\mathrm{Cl}$. More positive values of HCP due to the increasing the cover depth can be observed in the work of other researchers [30].

\subsubsection{Cracked concrete beams}

In beams containing $\mathrm{W} 1$ cracks, with the cover depth of $\mathrm{C} 1$ and without nano-silica (NSOW1C1), the average of $\mathrm{HCP}$ is $-400 \mathrm{mV}$. This value in beams with the cover depth of $\mathrm{C} 2$ is $-325 \mathrm{mV}$. So, the average values of potential difference are $19 \%$ more positive, indicating the effect of cover depth in changing the values of half-cell potential.

The values of HCP in the concrete depend on the amount of existing Oxygen. Cracking in the concrete and decreasing the cover depth make Oxygen to be sufficiently present in intensifying corrosion and, in turn, makes the half-cell potential values more negative [31].

In beams containing $1.5 \%$ of nano-silica, the average value of HCP is $-332 \mathrm{mV}$ with the cover depth of $30 \mathrm{~mm}$ (NS1W1C1), which becomes $45 \%$ more positive and reaches $-252 \mathrm{mV}$ as the cover depth increases to $45 \mathrm{~mm}$ (NS1W1C2). These changes in the samples of NS1W2C2,
NS1W3C2 and NS1W4C are $22 \%, 22 \%$, and $19 \%$, respectively, compared to similar samples of $\mathrm{C} 1$.

In beams containing $3 \%$ of nano-silica ( $\mathrm{NS} 2 \mathrm{~W} 1 \mathrm{C} 1$ ), the average value of half-cell potential for the cover $\mathrm{C} 1$ is $-362 \mathrm{mV}$, which changes to $-284 \mathrm{mV}$ in the cover $\mathrm{C} 2(22 \%$ positive). These changes in the samples of NS2W2C2, $\mathrm{NS} 2 \mathrm{~W} 3 \mathrm{C} 2$, and $\mathrm{NS} 2 \mathrm{~W} 4 \mathrm{C} 2$, as compared to the similar samples of $\mathrm{C} 1$, are $20 \%, 23 \%$, and $20 \%$, respectively. The proximity of the values of the half-cell potential in cracks with a more width (W3 and W4) shows that the cover depth has little effect in this range, and accordingly, the values of HCP are more negative.

The proposed model of half-cell potential as a function of crack width and nano-silica parentages for two cases of cover is shown in Fig. 8.

The proposed models for HCP can be expressed with the following equation:

For cover $\mathrm{C} 1=30 \mathrm{~mm}$ :

$$
H C P_{C 1}=a+b \times N S+c \times w+d \times(N S)^{2}+e \times w^{2},
$$

where,

$$
\begin{aligned}
& a=2.89788005027454 \times 10^{2}, \\
& b=-5.72527541948998 \times 10, \\
& c=1.01076040071530 \times 10^{3}, \\
& d=1.63420091589887 \times 10, \\
& e=-8.22829469207916 \times 10^{2} .
\end{aligned}
$$

For cover $\mathrm{C} 2=45 \mathrm{~mm}$ :

$$
H C P_{C 2}=a+b \times N S+c \times w+d \times(N S)^{2}+e \times w^{2},
$$

where,

$$
\begin{aligned}
& a=2.37539579684989 \times 10^{2}, \\
& b=-6.22674795130165 \times 10, \\
& c=7.92278986826636 \times 10^{2}, \\
& d=1.68625914962759 \times 10, \\
& e=-5.45649833646198 \times 10^{2} .
\end{aligned}
$$

In these models, obtained $R^{2}$ values indicate the high accuracy of the empirical models. 


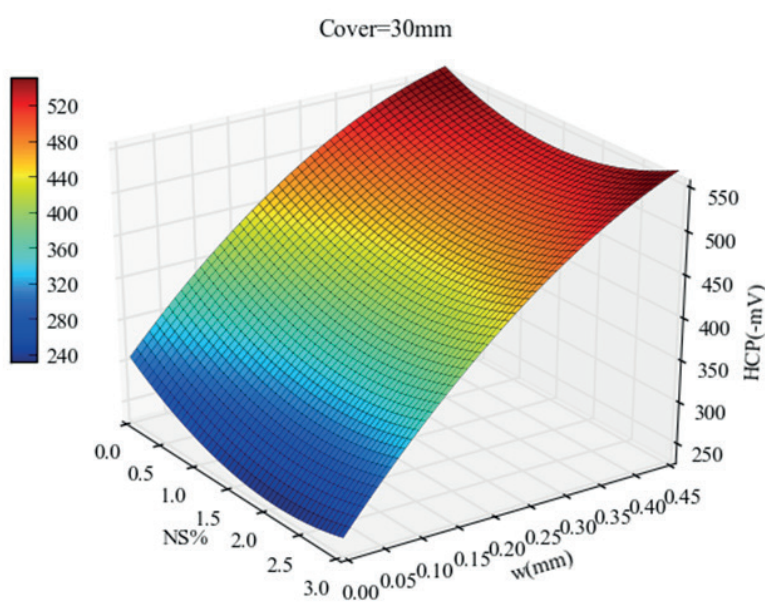

(a)

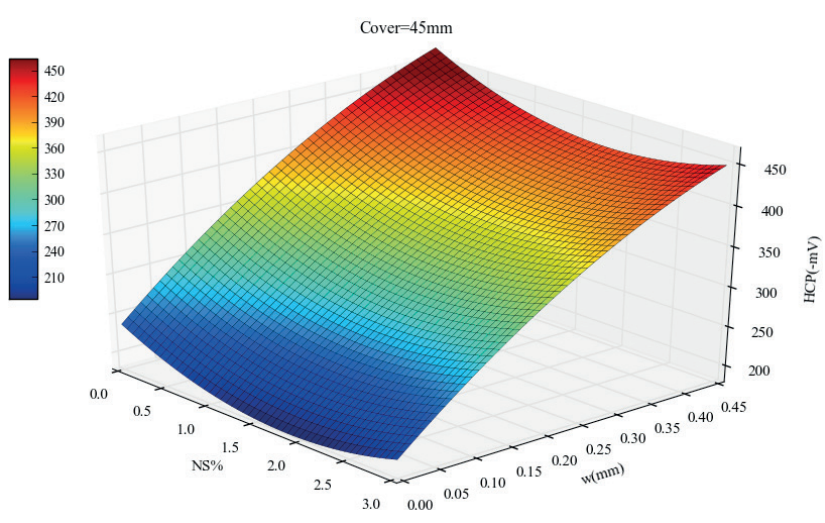

(b)

Fig. 8 HCP models for various conditions of crack width and nanosilica: (a) cover $\mathrm{C} 1=30 \mathrm{~mm}$, (b) cover $\mathrm{C} 2=45 \mathrm{~mm}$

\subsection{Crack effect on the values of diffusion factor in different percentage of nano-silica}

The diffusion coefficient of the cracked concrete differs from that in sound condition. The ratio of chloride diffusion coefficient in cracked concrete to diffusion coefficient in sound concrete is called the "integrated effect coefficient" [32]. For crack widths between $0.1 \sim 0.3 \mathrm{~mm}$, the increase of ratio is almost constant. For crack widths greater than $0.3 \mathrm{~mm}$, the increasing rate is faster [33].

In the current study, Fick's second law is used to describe the penetration of chloride in the concrete. In cracked concrete, the apparent chloride diffusion coefficient is not the actual diffusion coefficient, so it is called the "equivalent diffusion coefficient" [33].

Different equations have been proposed by researchers to determine the chloride diffusion coefficient in cracked concrete. Kwon et al. [29] assumed that the crack width could be considered as a controlling factor in obtaining the function of the diffusion coefficient in cracked concrete structures according to the following equation:
$D_{a}(w)=\left(31.61 w^{2}+4.73 w+1\right) \cdot D_{a}(w \geq 0.1 \mathrm{~mm})$,

where $D_{a}(w)$ is the chloride diffusion coefficient in cracked concrete, and $D_{a}$ indicates the diffusion coefficient in sound concrete. $w$ is the width of the surface crack.

Similarly, Zhang et al. [33] proposed a quadratic function as:

$D_{a}(w)=\left(47.18 w^{2}-8.18 w+1\right) \cdot D_{a}(w \geq 0.1 \mathrm{~mm})$,

Moreover, Lu et al. [32] proposed the following relationship for predicting the diffusion factor in cracked concrete structures:

$D_{a}(w)=K \cdot D_{a}$

$K=\left\{\begin{array}{ll}1, & w \leq 0.05 \mathrm{~mm} \\ 173.2 w-7.66, & 0.05 \mathrm{~mm}<w \leq 0.10 \mathrm{~mm} \\ 31.6 w+6.5, & 0.10 \mathrm{~mm}<w<0.35 \mathrm{~mm}\end{array}\right.$.

In the current study, the influence of crack width on chloride diffusion factor in different percentages of nano-silica is investigated. Fig. 9 shows the results of the chloride diffusion factor for cracked concrete with nano-silica.

$D_{\text {ref }}$ is the value of diffusion coefficient in sound beams (without nano-silica), and $\alpha=D / D_{\text {ref }}$ is the integrated effect coefficient. As can be seen, the use of nano-silica reduces the permeability of concrete. This is due to the nano-filler effect and the pozzolanic reaction, which results in less porosity, particularly at the interfacial transition zone [18].

As shown in Fig. 9, changes in graph slope is greater in NS0 samples (without nano-silica) compared to NS1 and NS2 samples. The quadratic function for NS0 samples could be used as:

$\alpha=17.963\left(w_{c r}\right)^{2}+7.8833\left(w_{c r}\right)+0.8861$,

$R^{2}=0.9889$.

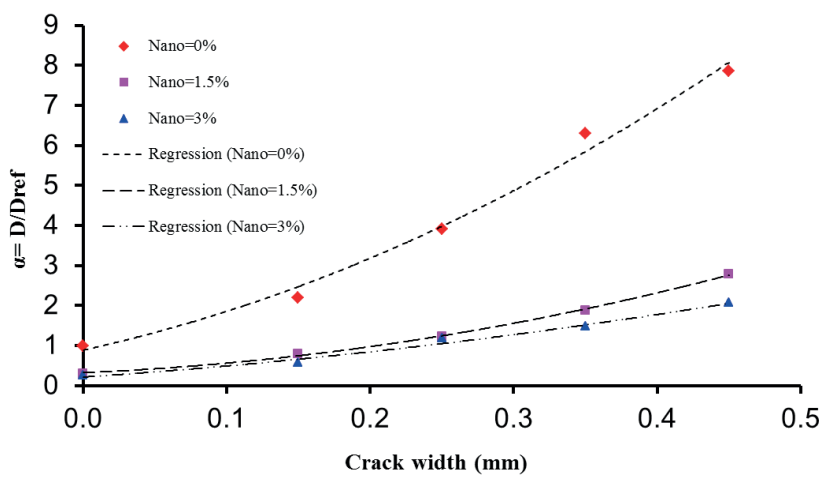

Fig. 9 Relationship between $\alpha$ and crack width 
According to Fig. 9, the value of $\alpha$ in NS1 samples (with nano-silica percentage of $1.5 \%$ ) has decreased significantly compared to NS0. This shows that the nano-silica in the mixed design of concrete improves the structure of the concrete matrix and increases the service life of $\mathrm{RC}$ structures. In NS2 samples (with nano-silica percentage of $3 \%$ ), the decrease in $\alpha$ did not show a significant change compared to NS1, so the average value of this decrease was about $20 \%$.

The quadratic functions for NS1 and NS2 samples can be expressed by the following equation, respectively:

for NS1:

$\alpha=8.6441\left(w_{c r}\right)^{2}+1.5259\left(w_{c r}\right)+0.3222$,

$R^{2}=0.9885$.

for NS2:

$\alpha=3.737\left(w_{c r}\right)^{2}+2.4107\left(w_{c r}\right)+0.213$,

$R^{2}=0.9988$.

These equations indicate a perfect match between the regression function and experimental values. So the diffusion coefficient in cracked concrete structures can be estimated by using these equations in a similar study.

Here, three functions are chosen for comparison to test data of NS0 (without nano-silica). As can be seen in Fig. 10, the results of the current study are close to those of Kwon et al. [29] and Zhang et al. [33], but have a lot of difference with results of Lu et al. [32].

\section{Conclusions}

This study was conducted to investigate the effect of various crack widths and nano-silica percentages on the chloride diffusion factor and half-cell potential. The following conclusions can be drawn based on the test results:

1. HCP was measured for sound concrete exposed to aggressive conditions. The average values of half-cell potential for sound concrete beams in the three categories of nano-silica $(0 \%, 1.5 \%, 3 \%)$ are $-243 \mathrm{mV},-185 \mathrm{mV}$ and $-218 \mathrm{mV}$, respectively. The results show that, with increasing nano-silica level to $1.5 \%$, HCP values become about $24 \%$ more positive, which indicates the improved behavior of concrete against corrosion. However, by increasing the

\section{References}

[1] Choucha, S., Benyahia, A., Ghrici, M., Mansour, M. S. "Effect of natural pozzolan content on the properties of engineered cementitious composites as repair material", Frontiers of Structural and Civil Engineering, 12(3), pp. 261-269, 2018.

https://doi.org/10.1007/s11709-017-0394-X

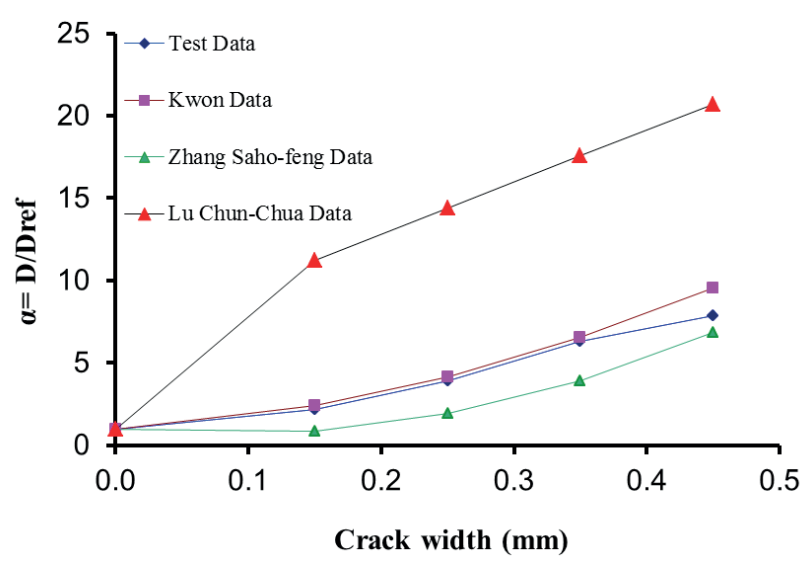

Fig. 10 Comparison of results with other studies

amount of nano-silica to $3 \%$, the potential difference average values become $18 \%$ more negative compared to the nano-silica percentage of $1.5 \%$.

2. HCP measurements increase as the crack width developed. Cracks speed up corrosion induced by chloride through increasing concrete permeability. In general, steel corrosion increases as the crack width extend, but is sensitive to concrete quality. The average values of half-cell potential for $\mathrm{W} 1$ crack in the three categories of NS0 to NS2 are $-325 \mathrm{mV},-252 \mathrm{mV}$, and $-284 \mathrm{mV}$, respectively. Half-cell potential values of NS1 compared to NS2 in crack width of W1 also shows a more positive value. In W3 and W4, differences in HCP values are less as compared to the results of $\mathrm{W} 1$ to $\mathrm{W} 2$, but values in NS1 are relatively more positive. So it shows that the specimens with $1.5 \%$ nano-silica (NS1) had a better performance against corrosion.

3. In beams containing nano-silica with the cover depth of $30 \mathrm{~mm}$ (NS1W1C1), the average value of HCP is $-332 \mathrm{mV}$, which becomes $45 \%$ more positive and reaches to value of $-252 \mathrm{mV}$ as the cover depth increases to $45 \mathrm{~mm}$. These changes in the samples of NS1W2C2, NS1W3C2, and NS1W4C2 are $22 \%, 22 \%$, and $19 \%$, respectively, as compared to the similar samples of $\mathrm{C} 1$.

4. Based on the test results, HCP evaluation equations were proposed to influence parameters (nano-silica and crack width) for two different cover depths.

5. Regression models were proposed for HCP and diffusion coefficient values in cracked concrete beams containing nano-silica.

[2] Hernández, E. F., Cano-Barrita, P. F. de J., Torres-Acosta, A. A. "Influence of cactus mucilage and marine brown algae extract on the compressive strength and durability of concrete", Materiales de Construccion, 66(321), Article ID e074, 2016. https://doi.org/10.3989/mc.2016.07514 
[3] Muthulingam, S., Rao, B. N. "Chloride binding and time-dependent surface chloride content models for fly ash concrete", Frontiers of Structural and Civil Engineering, 10(1), pp. 112-120, 2016. https://oi.org/10.1007/s11709-015-0322-x

[4] Bertolini, L., Elsener, B., Pedeferri, P., Redaelli, E., Polder, R. B. "Corrosion of Steel in Concrete: Prevention, Diagnosis, Repair", 2nd ed., Wiley-VCH, Weinheim, Germany, 2014.

[5] CEB "N॰183 Durable Concrete Structures - CEB Design Guide", Comité Euro-International du Béton, Lausanne, Switzerland, 1992. [online] Available at: https://www.fib-international.org/publications/ceb-bulletins/durable-concrete-structures-pdf-detail.html

[6] Mindess, S., Young, J. F. "Concrete", Prentice-Hall, Englewood Cliffs, NJ, USA, 1981.

[7] Ismail, M., Toumi, A., François, R., Gagné, R. "Effect of crack opening on the local diffusion of chloride in cracked mortar samples", Cement and Concrete Research, 38(8-9), pp. 1106-1111, 2008. https://doi.org/10.1016/j.cemconres.2008.03.009

[8] Yoon, S., Wang, K., Weiss, W. J., Shah, S. P. "Interaction between Loading, Corrosion, and Serviceability of Reinforced Concrete", ACI Materials Journal, 97(6), pp. 637-644, 2000. https://doi.org/10.14359/9977

[9] Chen, E., Berrocal, C. G., Löfgren, I., Lundgren, K. "Correlation between concrete cracks and corrosion characteristics of steel reinforcement in pre-cracked plain and fibre-reinforced concrete beams", Materials and Structures, 53(2), Article number: 33, 2020. https://doi.org/10.1617/s11527-020-01466-Z

[10] Raharinaivo, A., Brevet, P., Grimaldi, G., Pannier, G. "Relationships Between Concrete Deterioration and Reinforcing-Steel Corrosion", Durability of Building Materials, 4(2), pp. 97-112, 1986.

[11] Arya, C., Ofori-Darko, F. K. "Influence of crack frequency on reinforcement corrosion in concrete", Cement and Concrete Research, 26(3), pp. 345-353, 1996.

https://doi.org/10.1016/S0008-8846(96)85022-8

[12] Otieno, M. B., Alexander, M. G., Beushausen, H.-D. "Corrosion in cracked and uncracked concrete - influence of crack width, concrete quality and crack reopening", Magazine of Concrete Research, 62(6), pp. 393-404, 2010.

https://doi.org/10.1680/macr.2010.62.6.393

[13] Hosseini, P., Mohamad, M. I., Nekooie, M. A., Taherkhani, R., Booshehrian, A. "Toward green revolution in concrete industry: The role of nanotechnology (A review)", Australian Journal of Basic and Applied Sciences, 5(12), pp. 2768-2782, 2011.

[14] Pacheco-Torgal, F., Jalali, S. "Nanotechnology: Advantages and drawbacks in the field of construction and building materials", Construction and Building Materials, 25(2), pp. 582-590, 2011. https://doi.org/10.1016/j.conbuildmat.2010.07.009

[15] Haruehansapong, S., Pulngern, T., Chucheepsakul, S. "Effect of the particle size of nanosilica on the compressive strength and the optimum replacement content of cement mortar containing nano- $\mathrm{SiO}_{2}{ }^{\prime \prime}$, Construction and Building Materials, 50, pp. 471-477, 2014. https://doi.org/10.1016/j.conbuildmat.2013.10.002

[16] Zhang, P., Wan, J., Wang, K., Li, Q. "Influence of nano- $\mathrm{SiO}_{2}$ on properties of fresh and hardened high performance concrete: A state-of-the-art review", Construction and Building Materials, 148, pp. 648-658, 2017.

https://doi.org/10.1016/j.conbuildmat.2017.05.059
[17] Ismael, R., Silva, J. V., Carmo, R. N. F., Soldado, E., Lourenço, C., Costa, H., Júlio, E. "Influence of nano- $\mathrm{SiO}_{2}$ and nano- $\mathrm{Al}_{2} \mathrm{O}_{3}$ additions on steel-to-concrete bonding", Construction and Building Materials, 125, pp. 1080-1092, 2016.

https://doi.org/10.1016/j.conbuildmat.2016.08.152

[18] Du, H., Du, S., Liu, X. "Durability performances of concrete with nano-silica", Construction and Building Materials, 73, pp. 705-712, 2014.

https://doi.org/10.1016/j.conbuildmat.2014.10.014

[19] Heikal, M., Abd El Aleem, S., Morsi, W. M. "Characteristics of blended cements containing nano-silica", HBRC Journal, 9(3), pp. 243-255, 2013.

https://doi.org/10.1016/j.hbrcj.2013.09.001

[20] Kim, Y. Y., Kim, J. M., Bang, J.-W., Kwon, S.-J. "Effect of cover depth, w/c ratio, and crack width on half cell potential in cracked concrete exposed to salt sprayed condition", Construction and Building Materials, 54, pp. 636-645, 2014.

https://doi.org/10.1016/j.conbuildmat.2014.01.009

[21] ASTM "ASTM C876 - 15 Standard Test Method for Corrosion Potentials of Uncoated Reinforcing Steel in Concrete", ASTM International, West Conshohocken, PA, USA, 2015. https://doi.org/10.1520/C0876-15

[22] Gao, Y., Zhang, J., Zhang, S., Zhang, Y. "Probability distribution of convection zone depth of chloride in concrete in a marine tidal environment", Construction and Building Materials, 140, pp. 485495, 2017.

https://doi.org/10.1016/j.conbuildmat.2017.02.134

[23] Farahani, A., Taghaddos, H., Shekarchi, M. "Prediction of long-term chloride diffusion in silica fume concrete in a marine environment", Cement and Concrete Composites, 59, pp. 10-17, 2015. https://doi.org/10.1016/j.cemconcomp.2015.03.006

[24] ASTM "ASTM C150 / C150M - 11 Standard Specification for Portland Cement", ASTM International, West Conshohocken, PA, USA, 2011. https://doi.org/10.1520/C0150_C0150M-11

[25] ASTM "ASTM C33-03 Standard Specification for Concrete Aggregates", ASTM International, West Conshohocken, PA, USA, 2003. https://doi.org/10.1520/C0033-03

[26] Nosratzehi, N., Miri, M. "Experimental Investigation on Chloride Diffusion Coefficient of Self-Consolidating Concrete in the Oman Sea", Periodica Polytechnica Civil Engineering, 64(3), pp. 647657, 2020.

https://doi.org/10.3311/PPci.15335

[27] NORDTEST "Concrete, hardened: Accelerated chloride penetration", NORDTEST, Taastrup, Denmark, Rep. NT BUILD 443, 1995. [online] Available at: http://www.nordtest.info/wp/1995/11/22/ concrete-hardened-accelerated-chloride-penetration-nt-build-443/

[28] Sadati, S., Moradllo, M. K., Shekarchi, M. "Long-term durability of onshore coated concrete - chloride ion and carbonation effects", Frontiers of Structural and Civil Engineering, 10(2), pp. 150-161, 2016. https://doi.org/10.1007/s11709-016-0341-2

[29] Kwon, S. J., Na, U. J., Park, S. S., Jung, S. H. "Service life prediction of concrete wharves with early-aged crack: Probabilistic approach for chloride diffusion", Structural Safety, 31(1), pp. 75-83, 2009. https://doi.org/10.1016/j.strusafe.2008.03.004 
[30] Kwon, S.-J., Na, U.-J. "Prediction of Durability for RC Columns with Crack and Joint under Carbonation Based on Probabilistic Approach", International Journal of Concrete Structures and Materials, 5(1), pp. 11-18, 2011. https://doi.org/10.4334/ijcsm.2011.5.1.011

[31] Elsener, B., Andrade, C., Gulikers, J., Polder, R., Raupach, M. "Half-cell potential measurements - Potential mapping on reinforced concrete structures", Materials and Structures/Materiaux et Constructions, 36, pp. 461-471, 2003.

https://doi.org/10.1007/BF02481526
[32] Lu, C., Cui, Z., Liu, R., Liu, Q. "Chloride diffusivity in flexural cracked Portland cement concrete and fly ash concrete beams", Journal of Central South University, 21, pp. 3682-3691, 2014. https://doi.org/10.1007/s11771-014-2351-3

[33] Zhang, S., Lu, C., Liu, R. "Experimental determination of chloride penetration in cracked concrete beams", Procedia Engineering, 24, pp. 380-384, 2011

https://doi.org/10.1016/j.proeng.2011.11.2661 